\title{
DEMOCRATIC PRINCIPLES BEHIND EMPLOYMENT LAWS AND THEIR APPLICATION IN KOGI STATE OF NIGERIA, 2016-2019
}

\author{
Francis Ohiemi Edimeh; Richard Adewale Elewomawu \\ Department of History, Kogi State College of Education, Ankpa, Kogi State, Nigeria.
}

\begin{abstract}
National and international labour and employment laws are based on the democratic ideals of justice, fairness, prevention of exploitation and poverty as well as the attainment of the general good of workers. Based on this background, this paper juxtaposed laid down terms and conditions of employment with how civil servants in Kogi State of Nigeria have fared under their employer, the Kogi State Government over a period of three years. It was established that through non-payment, delayed payment or payment of incomplete salaries and pensions as well as other labour-hostile actions, the Kogi State government had failed to respect democratic principles as pertains to labour relations. By so doing, the state government had inflicted economic, social and psychological injuries on its workers. Interrogating this situation, factors implicated include corruption, mismanagement of funds and undemocratic prioritization. However, this paper identified judicial and legislative measures that can ameliorate the plight of workers. The workers themselves were advised to beware of the caliber of people they select to represent them in their unions.
\end{abstract}

Keywords: Democracy, Labour, Employment. Civil Servants

\section{INTRODUCTION}

Democracy is meant to permeate all aspects of life in society. Wherever it is taken as the norm, it regulates the political, legal, social and economic lives of citizens. Workers are not exceptions. Employment laws as well as labour organizations and multilateral agreements have the aims of making workers enjoy democratic gains and protection. Apart from entitlement to the fundamental human rights, workers are also entitled to other rights and benefits as conditions of their employment. Thus, bodies such as the International Labour Organization (ILO), multilateral agreements such as the Universal Declaration of Human Rights, the International Convention for Economic, Social and Cultural Rights, the African Charter on Human and People's Rights, etc as well as national labour laws such as those of Nigeria, have all set the standards for the attainment of the democratic ideals for employees both as human beings and as pertains to their labour 


\section{International Journal of Arts and Humanities}

ISSN: 2581-3102

Volume: 04, Issue: 02 "February 2020"

services. The set standards are all geared towards the achievement of justice, fairness, equity, freedom from exploitation, poverty, enslavement and oppression.

Nigeria is a signatory to organizations, conventions and charters which set labour standards, yet it contravenes them. The constituent State governments in Nigeria are worse culprits. They deny their civil servants the rights which they are entitled to under the employment contract, thus inflicting economic, social, legal and psychological injury on the workers. This has been the lot of the civil servants in Kogi State in the last three years, more than previously.

Kogi State was created along with six others as constituents of the Nigerian Federation in 1996. The State can be described as a civil service state. This is because, lacking in industries and remarkable economic ventures, the civil service becomes the hub of livelihood in the state. So, when there is a prolonged distortion in the income of civil servants, it is easy to imagine the poverty level of the state. Since inception, the governments that succeeded to power had been battling with the low economic base of the State and the challenges of meeting social responsibilities. Thus, they sometimes delayed in paying workers' salaries. The government that left power in 2015 had two months' arrears of salaries unpaid. However, the succeeding one has a mind boggling record of labour abuses in three years.

On January 27, 2016, Alhaji Yahaya Bello came into office as the Executive Governor of Kogi State. He was a beneficiary of the grievous disease that has infected the reconciliation, resolution and social cohesion mechanism of the Igala, the most populous ethnic nationality in the State; and eventually, the death of the leading contender in the Governorship race. However, Bello has acted just like Chinua Achebe's man whose palm kernels were broken for him by the gods. Under his administration, employees of the state government have been groaning.

The focus of this paper is to show that the extent to which the workers are maltreated by the Kogi State government during the period under review amounted to the violation of the democratic principles underlying the provisions of international and national labour organizations as well as human rights conventions, charters and declarations. In doing so, there shall be a definition of the concept of democracy, followed by a relevant conceptual framework to gird the position of the paper. There shall also be a cursory survey of major labour organizations, as well as multilateral agreements and their conditions of employment and human rights. Next is the section that examines the record of the labour relations between the Kogi State government and her civil servants and pensioners in the last three years. Finally, while a conclusion shall be drawn, recommendations shall also be made.

\section{CLARIFICATION OF CONCEPT}

\section{Democracy}


International Journal of Arts and Humanities

ISSN: 2581-3102

Volume: 04, Issue: 02 "February 2020"

The term democracy derives from two Greek words. 'Demos' refers to the people while 'kratia' means to rule. Put together, the words mean rule of the people (Encyclopedia Britannica 2010). Even as widely accepted as the practice of democracy is, its definition is not commonly accepted. Democracy can be seen as a form of government. Thus, Abraham Lincoln popularly defines it as government of the people, by the people and for the people (Agaba 2019). This definition denotes popular consent, popular participation as well as the idea that government is meant to serve the good of the people. For Dicey, in a democracy, the governing body is a comparatively large fraction of the entire nation (quoted in Asirvatham \& Misra 2009). The Encarta Dictionaries on its part sees democracy as a system of government based on the principles of majority decision making.

For some scholars, democracy is not merely a form of government. They view it as a type of state. This is because the community as a whole has sovereign authority and maintains ultimate control over its affairs. This perspective criticizes the idea of looking at democracy as merely a mode of appointing, controlling and dismissing a government. This is the prevalent picture in fledgling democracies in which elections represent the be-all-and-end-all of democratic participation (Agaba, 2019). Yet another school of thought views democracy as an order of society. As such, the spirit of equality and fraternity prevails within the resulting humane polity. There is also a pattern of civility rooted in respect and justice for each man (Asirvatham \& Misra, 2009). At this point let us note that this is the aspect that especially Third World societies, including Nigeria find difficult. They formally adopt the democratic form of government without a commensurate democratization of their societies. Thus, misuse of power, high handedness, and disregard of the rule of law, incivility, among other misbehaviors are common in the Third World.

However, it should be noted that democracy is not a static entity. Culture and society influence people's democratic ideals. Thus, by using some standard of measurement, some polities are referred to as developed or advanced democracies while others are considered as developing democracies. The former which are found mostly in Europe and America are considered to be the shining stars of democracy. On the other hand, the high tide of democratic perfection is yet to arrive in most parts of Africa, Asia and Latin America. Also, democracy cannot be assessed in the same way for all time frames (Satori, 1968).

Finally, the idea that democracy is the product of the exclusive innovative ability of Western Civilization is erroneous. It is true that the Athenian Greeks adopted the political practice to which they gave the name democracy in $500 \mathrm{BC}$. Yet, evidence suggests that democratic government in a broad sense existed in several parts of the world much earlier than $5^{\text {th }}$ century 
International Journal of Arts and Humanities

ISSN: 2581-3102

Volume: 04, Issue: 02 "February 2020"

BC (Encyclopedia Britannica2010). Democracy, like all forms of government and social order evolve out of the geographical, social and political experiences of social groups (Edimeh 2015).

However, there are certain basic qualities of democracy no matter the society or period. They include the following: Popular consent, Popular participation, Equitable representation, Accountability, Consensus, Human Rights and Impartial justice. (Agaba 2019)

\section{Employment Laws}

Employment is a relation between two parties usually based on a contract where work is paid for and where one party is the employer and the other employees. Employees work in return for payment while the employment is typically based on regulations, legal contracts and employment laws. Employment laws usually apply to workers where the legal relations are directly between the employer and employee. It refers to the regulation in statute law that establishes minimum conditions relating to the employment of persons such as the minimum working age, minimum wage, etc (https://en.wikipedia.org/wiki/Employment)

\section{THEORETICAL FRAMEWORK}

This paper is girded by the Human Needs Theory. Since workers offer their labour in return for payment for the sole purpose of satisfying their needs, this theory will help to assess whether the Kogi State workers are getting a fair deal from their employers. Abraham Maslow propounded a theory of human motivation in which he identified a hierarchy of needs. The first in the order of needs is the physiological needs. These are the physical requirements for human survival. Air, water and food are metabolic requirements for human existence. Clothing and shelter give protection from the elements.

The second most important need of man is safety or security. This includes personal security, financial security as well as health and well-being. Then there is the human need for love and a sense of belonging. This can be satisfied through friendship, intimacy and family. There is also the need for self esteem. This is the human desire to be valued and accepted by others. Finally, there is a need for self actualization (en.wikipedia.org\% 27 s.heirarchy of needs).

Burton (1979), in a further development of the human needs theory posited that deep rooted social conflicts arise from unsatisfied basic needs. Imobighe (1983) also views security from a socio-economic perspective. Thus, to him, security is the ability of the state to provide the atmosphere under which it could satisfy the physical as well as the psychological needs of its inhabitants. Abubakar (2004) defines security as the struggle to secure the basic necessities of life. McNamara concluded that man's security did not lie in his weapons but in his mind. That is, 
International Journal of Arts and Humanities

ISSN: 2581-3102

Volume: 04, Issue: 02 "February 2020"

that his security lies in the satisfaction of his physical and psychological needs. Finally, Ochoche (1980) identifies hunger, poverty, illiteracy and disease as social threats to security.

From the human needs theory, it can easily be seen that by non-payment of salaries, pensions and other entitlements to workers and retirees, the Kogi State government is denying them of their fundamental needs. By denying them of their source of livelihood, the government has grossly degenerated the quality of their lives. The workers and pensioners under this condition are unable to adequately provide for their physical and psychological needs and those of their families. And they lack financial security. However, before going into particular details, it is pertinent to briefly look at the stand of labour and human rights organizations as well as multilateral agreements.

\section{The International Labour Organisation (ILO)}

The International Labour Organisation (ILO) is one hundred years old now, being one of the earliest extra national bodies created in the world. It also has a record of being the first specialized agency of the United Nations. The Organisation was constituted by the Treaty of Versailles in 1919 as part of the efforts to bring lasting peace and harmony to the international space after the devastating Second World War. It was founded on the principle that labour is not a commodity and that lasting peace can be established only if it is based on social justice. Thus, the Organization was charged with advancing social justice, human development and the promotion of human welfare. The ILO provided the avenue and the instrument for the resolution of the antagonisms that existed in human societies. By this way, it was hoped that peaceful progress would be achieved.

The ILO has 187 member states and is tripartite in its assignment. It brings together governments, employers and workers. The organization is the foremost and umbrella labour organization which sets international labour standards. It is also charged with the task of developing policies and devising programmes for promoting decent working conditions for all men and women all over the world. As an organization whose responsibility it is to protect and advocate for workers and labour unions, the ILO categorically states that workers have the right to a living wage. In 1998, the Declaration on Fundamental Principles and Rights at Work was issued (Wikipedia.Ilo.org). Nigeria is a member of the ILO.

\section{The International Covenant on Economic, Social and Cultural Rights (1976)}

Nigeria is also a signatory of the International Covenant on Economic, Social and Cultural Rights. As such, she is bound to recognize and make all its declared rights enforceable and justiciable in the country. The rights of citizens contained in the Covenant include the following: Right to work, Right to choice of employment, Right to adequate standard of living, Right to 
access to education, Right to form family and to the respect and protection of the family, Right to social security and Right to adequate nutrition (Iweoha, 2017).

\section{The Universal Declaration of Human Rights}

In Article 23, this Declaration affirms workers' right to just and favorable remuneration, among others. This right, it maintains is predicated on the fact that workers contribute to the creation of wealth. It categorically declared that non payment of salaries is a complete denial of a worker's right. And Article 25 spells out the citizen's right to adequate physical and mental health and well being of the family, including the provision of food, clothing and housing. It also holds that the provision of poverty alleviation and empowerment facilities is based on the principles that all men should be protected against poverty.

\section{The African Charter on Human and People's Rights.}

This Charter which Nigeria has ratified, holds sacrosanct the philosophy that the human person is the central subject of development and to actualize development rights is to enable him to attain the highest form of civilization. It holds the germane idea that citizens are the distinguished elements in any polity or democracy. Therefore, their fundamental rights must be protected. That is when they can better render their contribution for the effective democratization and overall development of their nation (Iweoha, 2017).

The Constitution of The Federal Republic of Nigeria stipulates the duties of State Governors in Chapter 10, sections 13-15. They include

- Promotion of democracy and social justice

- Promotion of the security and well being of citizens

- Provision of adequate facilities, goods and services that improve the well being of all citizens

- Provision of adequate shelter, food, resources, wages, education and health of all citizens

(Constitution of the Federal Republic of Nigeria).

These few examples are meant to show the international institutions and instruments involved in the efforts to bring about a peaceful, humane and progressive world. Nigeria is a member/signatory to these bodies and declarations. Yet, within her boundary, gross and protracted violations take place.

The Undemocratic Treatment of Workers in Kogi State 2016-2019 
International Journal of Arts and Humanities

ISSN: 2581-3102

Volume: 04, Issue: 02 "February 2020"

One of the earliest actions of the administration of Alhaji Yahaya Bello when he came into office in 2016 as Governor of Kogi State was to embark on staff auditing. The intention was good as the exercise was to fish out ghost workers and pensioners, trim the wage bill and make the civil service more efficient. However, the exercise became protracted, muddled up and discredited. The workers and retirees bore the brunt. Including the old and infirm, they were all dragged to the state capital. They stayed in uncomfortable and undignifying positions. Some lost their lives in road accidents while others had their health conditions worsened. That is not to talk of the harassment and trauma that they went through. A worker or pensioner could have his or her name "cleared" in one month only to become "uncleared" the next month. Among the fallout of the staff screening was the labor-hostile act of retiring civil servants before the date stipulated in their employment contract and without paying their severance entitlements. This is a contravention of all known employment and labour laws. Some retirees are not even placed on pension for a long time. And the mode of staff auditing embarked upon by the State Government is an embarrassment to the present digital age of the $21^{\text {st }}$ century.

The worst aspect is that instead of the staff auditing resulting in ease of payment of salaries and pensions, the reverse has been the case. For the past three and a half years now Kogi State has been notorious for non payment, delayed payment and payment of fractions of salaries and pensions. In May, 2019, the Chairman of the Kogi State branch of the Nigeria Labour Congress, Comrade Onuh Edoka addressed His Excellency, Alhaji Yahaya Bello, the Executive Governor of Kogi State. He reminded him that his administration was "heavily indebted" to workers and pensioners due to non payment of their salaries, pensions and other entitlements. He categorically said that as at May, 2019, the outstanding salaries and pensions were in six categories and ranging from 8 to 39 months (https:www.pulse.ng).

Apart from salaries and pensions, leave bonuses were not paid, according to the labour leader, for 2016, 2017 and 2018. And 2019 is in its second half. This is in contravention of labour laws which entitles workers to paid holidays. And most disturbing is the fact that when workers and retirees, after waiting for several months to get their pay, it does not come full but in fractions. Recently, the Joint Action Union of Local Government Workers rejected the 25\% \& 30\% salaries paid to Local Government workers (Odogun, 2019). Moreover, workers get promoted without it reflecting in their pay.

There are obvious negative effects of non payment of salaries and pensions as at when due. It incapacitates citizens economically and socially, exposing them to poverty and ridicule. It makes them to be handicapped in providing food, shelter, clothing, education and other basic necessities for themselves and their families. The lack of good nutrition and inability to access healthcare due to lack of finance results in ill health and death. Apart from the physical effect, the mental 
International Journal of Arts and Humanities

ISSN: 2581-3102

Volume: 04, Issue: 02 "February 2020"

and psychological impacts are grave. The image of a parent who cannot carry out his or her responsibilities is a poor one before their families and communities. Or that of employed persons that are forced to beg, as the NLC Chairman, Kogi State Branch says workers are doing on the streets of Kogi (Akinfehinwa, 2019). Thus, workers and pensioners are subjected to a life shorn of human dignity. The mental agony is an invitation to mental health challenges. The result can also be broken families and moral and material neglect of wives and children; or children dropping out of school, becoming deviants and candidates for armed robbery, prostitution, cyber crime and terrorism (Iweoha, 2017). As a result of non payment of salaries, the educational institutions that are not closed due to industrial action are dwarfed with the exit of qualified professionals. Health institutions suffer the same fate. In fact, the economy of the State is in comatose (Oladesu \& Azania, 2019).

\section{Reasons for Non Payment of Salaries and Pension}

One begins to wonder why the Kogi State government fails to or refuses to pay salaries, pensions and other entitlements, knowing full well that these are the sources of livelihood for workers, pensioners and their dependants. The importance of prompt payment of salaries, pensions and other entitlements cannot be overstated. The duty to pay workers' salaries and wages is derived from the terms of the contract of service between the workers and their employer. This duty which is implied at common law is protected in Part 1, sections $15 \& 17$ of the Nigerian Labour Law (1974) and entrenched in various international human rights instruments to which Nigeria is a signatory. This duty is taken as sacrosanct. In fact, in a contract of employment, the duty to pay the remuneration attached to a job is as important as the duty to do the job the employee was employed to do. In international labour laws, the employer is not even excusable from this duty by dire resource restraint or emergencies. Workers' remuneration still has to be paid to protect his dignity (Iweoha, 2017).

Unfortunately, the non payment of workers and pensioners by the Kogi State government is not even due to financial restraint. Instead, it is attributed partly to what has been described as "unprecedented corruption in the running of the state" (Daily Times, 25-06-2019). The Chairman, NLC in Kogi State, Comrade O. Edoka himself told the Governor that there was no moral justification for the present administration not to pay salaries and pensions having received bail out funds meant for that purpose in addition to several tranches of the Paris Club refund. The labour leader continued by saying that there is a moral burden on the Governor to explain what his administration has done with all the money received in addition to the monthly Federal allocation as well as the Internally Generated Revenue (IGR) which "runs into hundreds of billions of Naira" (pulse.ng 23-05-19). So, the possible explanations can be found in embezzlement and mismanagement of funds. The Governor is also guilty of what can be 
International Journal of Arts and Humanities

ISSN: 2581-3102

Volume: 04, Issue: 02 "February 2020"

described as undemocratic prioritization. What this means is that in his scale of preference, payment of salaries, pensions and other entitlements to workers and pensioners ranks low. What matters most in the mind of the Kogi helmsman has been political 'investments' that can make him retain power. Thus, he has doled out a lot of money to individuals and groups across the State who he thinks can help him retain power. He sponsors thugs and spent a lot of money for the fraudulent election of legislators who he hoped would repay the gestures in his own reelection bid. In his profligacy, the Governor is known to have given gifts of money and motor vehicles even to masquerades. Yet, he neglects the government's statutory duty of paying her employees.

\section{CONCLUSION}

The labour record of Kogi State in the past three and half years shows a flagrant contravention of the provisions of the ILO and human rights conventions and charters as well as Nigeria's labour laws. Therefore, workers and pensioners in the State are deprived of democratic dividends and protections. The non payment of the entitlements of workers and retirees has adverse economic, social and psychological effects on them. This situation has been going on for such a long time that people may think that it has come to stay.

However, there is a need and possibility of reversing the uncomfortable situation. Persistent judicial and legislative methods can help through the instrumentality of civil society groups. The Social and Economic Rights Advocacy Project (SERAP), has shown the possibility of suing State and Federal Government to the International Criminal Court (ICC). Civil Societies should continue to mount pressure on governments and parliaments. The States and Federal legislatures should enact laws that would enforce compliance with labour laws. The judiciary should go beyond statements about the illegality to enforce the laws in the cases concerning ill treatment of workers. Even then, some of the laws need to be updated. The workers themselves should help themselves by electing into their labour unions courageous, committed and credible persons. Above all, accountability needs to be enforced more strictly in Nigeria.

\section{REFERENCES}

Abubakar A. (2004). The challenges of security in Nigeria www.dawodu.com/abubakr/html.

Agaba, J. E (2019). 'Governance, leadership and development challenges: reflections on the two decades of democracy in Nigeria, 1999-2019'. Paper delivered at the $9^{\text {th }}$ National Conference on Democracy, Good Governance and Development in Nigeria: Issues, Challenges and Prospects, at the Kogi State College of Education, Ankpa. 12 July, 2019. 
International Journal of Arts and Humanities

ISSN: 2581-3102

Volume: 04, Issue: 02 "February 2020"

Akinfelhinwa J. (2019). 'Unpaid salaries: Kogi workers now beg on the streets: https://dailypost.ng/.../unpaid.salaries.Kogi-workers-now-beg-on-the-streets-NC/April 26, 2019.

Assirathan, E. \& Misra, K.K 2009. Political Theory, $13^{\text {th }}$ Edition. New Delhi: S.Chand \& Company.

Burton, J.W. (1979). Deviance, terrorist and war: the process of solving unsolved social and political problems Palgrave: Macmillan.

Dumelafrica.com. 'Kogi APC: factions disagree over mode for Guber Primary daily times newspaper 26/6/2019

Edimeh. F.O. (2015). Democracy in traditional Igala society, Lapai Journal Of Humanities: journal of the department of history and international studies, Ibrahim Badamasi Babangida University, Lapai. Vol. 9 no 22015

Encartar disctionaries. Microsoft students (2008) DVD. Redmond W.A Microsoft corp, 2007.

Encyclopedia Britannica (2010) 'Democracy" Encyclopedia Britannica students \& Home Edition. Chicago. Encyclopedia Britannica.

en. wikipedia.org\% $27 \mathrm{~s}$. hierarchy of needs.

https://en.wikipedia.org/wiki/employment.

https://punching.com.kog.lg.workers.reject.salary.payment.

https://www.pulsing >gzyhdr3

Imobighe, T.A. (1983) National security linkages. Paper presented at the Social Science Open Lectures University of Jos.

Iweoha, P.I. (2017). Non-payment of salaries: The implication on the legal, economic and social rights of workers in Nigeria. Public policy and administration research, vol 7, no, 2017

McNamata, R.S (2000). Argument without end. New York: Public Affairs

Ochoche, S.A. (1980). Towards the habilitation of the concept of security: Some preliminary sketches. Jos: Social Science Research Council.

Oladesu E. \& Azania, J. (2019). 'Can Bello get second term? The Nation Newspaper, Nigeria. 21st May, 2019. 